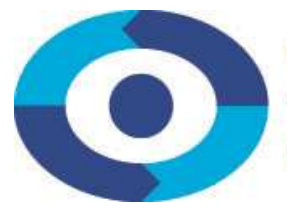

\title{
Vietnamese footwear export: The direction of trade and determinants of firms' market penetration
}

\author{
Vu Thi Hanh \\ Foreign Trade University (FTU), Vietnam \\ hanhvt@ftu.edu.vn

\section{Doan Quang Hung \\ Foreign Trade University (FTU), Vietnam \\ hungda@ftu.edu.vn}

We investigate determinants of firms' direction of trade by using panel data of Vietnam's footwear firms for the 2006-2010 period. Since no variance was found between firms, a pooled multinomial logit model is consequently preferable. Notably, the economies of scale show positive and significant effects for footwear firms serving the USA and EU markets. Although Vietnamese footwear firms are less likely to export to the ASEAN countries, they tend to focus on the diversification of products in this market. Both private and FDI firms are less likely to export to the EU compared with their counter parts owned by the State (SOEs). However, private firms outperform SOES in the U.S market.

Research for this paper was funded by the Swiss State Secretariat for Economic Affairs under the SECO / WTI Academic Cooperation Project, based at the World Trade Institute of the University of Bern, Switzerland.

SECO working papers are preliminary documents posted on the WTI website (WWW.Wti.Org) and widely circulated to stimulate discussion and critical comment. These papers have not been formally edited. Citations should refer to a "SECO I WTI Academic Cooperation Project" paper with appropriate reference made to the author(s). 


\title{
Vietnamese footwear export: The direction of trade and determinants of firms' market penetration
}

Hanh $\mathrm{Vu}^{l}$, Hung Doan

\begin{abstract}
We investigate determinants of firms' direction of trade by using panel data of Vietnam's footwear firms for the 2006-2010 period. Since no variance was found between firms, a pooled multinomial logit model is consequently preferable. Notably, the economies of scale show positive and significant effects for footwear firms serving the USA and EU markets. Although Vietnamese footwear firms are less likely to export to the ASEAN countries, they tend to focus on the diversification of products in this market. Both private and FDI firms are less likely to export to the EU compared with their counter parts owned by the State (SOEs). However, private firms outperform SOES in the U.S market.
\end{abstract}

Key words: Direction of trade, footwear, export firms, multinomial logit, Vietnam

\footnotetext{
${ }^{1}$ Vu Thi Hanh, Foreign Trade University, Vietnam, hanhvt@ftu.edu.vn
} 


\section{Introduction}

Trade liberalization and multilateral trade agreements have encouraged the development of international trade and foreign investment especially the export trade brings opportunity to serve foreign markets of local manufacturing firms. However, in order to confront market risks and improve their competitiveness, exporting firms need to continuously innovate and diversify their product and market ranges. However, importing countries such as the US and EU, with a variety of choices tend to impose trade barriers on products from less developed and developing countries including Vietnam. It is important to note that from 1998 to 2008, the EU had initiated 332 anti-dumping investigations ${ }^{2}$ in which $59 \%$ of cases involved Asian export and the USA is applying anti-dumping measures on shrimp from Vietnam ${ }^{3}$.

In recent years, Vietnam has been further integrating into the world economy and export has been contributing to the national income, creating more job opportunities and enhancing firms' productivity. Since the country implemented its Doi Moi policy in 1986, the export value of Vietnam increased remarkably from US\$39.8 billion in 2006 to US\$132 billion in 2013, equivalent to $60 \%$ and $77.1 \%$ of total GDP respectively. Notably, Vietnamese footwear industry ranks third in export value after crude oil and textiles, making up for about 7.2\% of total export turnover of Vietnam from the period of 20062013.

During this period, there are about 128 enterprises involving in the export of footwear products. These firms have been able to export to many countries around the world, especially to the prominent economies such as the EU, USA, ASEAN, China and Japan. From 2006 to 2010, the USA remained the biggest partner of Vietnam's footwear, at nearly US $\$ 1.5$ billion in 2010. It was followed by EU countries with US\$ 2.5 billion in the same year.

\footnotetext{
${ }^{2}$ http://ec.europa.eu/trade/issues/respectrules/anti_dumping/stat

${ }^{3}$ https://www.wto.org/english/tratop_e/dispu_e/cases_e/ds429_e.htm
} 
Table 1. Footwear firms' export market diversification

\begin{tabular}{|c|c|c|}
\hline \multirow[b]{2}{*}{ Number of export markets } & \multicolumn{2}{|c|}{ Period 2006-2010 } \\
\hline & $\begin{array}{c}\text { Percentage of firms } \\
(\%)\end{array}$ & $\begin{array}{c}\text { Percentage of export value } \\
(\%)\end{array}$ \\
\hline 1 & 45,69 & 0,41 \\
\hline 2 & 8,73 & 0,7 \\
\hline 3 & 5,97 & 0,39 \\
\hline 4 & 3,1 & 0,23 \\
\hline 5 & 2,66 & 0,54 \\
\hline 6 & 2,09 & 0,75 \\
\hline 7 & 1,69 & 0,57 \\
\hline 8 & 1,82 & 0,36 \\
\hline 9 & 1,02 & 0,37 \\
\hline 10 & 0,87 & 0,94 \\
\hline$>10$ & 1,06 & 94,5 \\
\hline Number of markets per firm & \multicolumn{2}{|r|}{9,17} \\
\hline $\begin{array}{l}\text { Maximum number of markets } \\
\text { per firm }\end{array}$ & \multicolumn{2}{|r|}{88} \\
\hline Number of firms & \multicolumn{2}{|r|}{128} \\
\hline
\end{tabular}

Source: Authors' calculation (STATA 14.0)

It is also worth noting that footwear exporting firms of Vietnam have achieved a diverse development in terms of market value (Table 1). Although the percentage of firms being able to export to only one market was very high, the export value was relatively low. Conversely, there were only a limited number of firms which can diversify their export markets but account for a larger share of total exports especially for the enterprises being able to export footwear product to 10 markets. It is clearly showed that Vietnamese footwear firms are very different in terms of export capacity.

During this period, there are about 128 enterprises involving in the production and export of footwear products. These firms have been able to supply in many countries especially in largest economies such as the EU, USA, ASEAN, China, Korea and Japan. From 2006 to 2010, the USA remained the biggest partner of Vietnam's footwear, at nearly US\$1.5 billion in 2010. It was followed by EU countries with US\$ 2.5 billion in the same year.

Firms in their process of destination-specific internationalization may be faced with both external and internal challenges. In some small and emerging economies such as Vietnam, it is impossible to discuss the issues of firm's internationalization without trade orientation 
as well as destination-specific internationalization. In the internationalization process, firms tend to expand their scope of activities with the aim to increase their economies of scale. As a result, there is the causality between economies of scale and international trade and countries with the relatively large share in domestic market are more likely to be exporter of such goods (Krugman, 1980). Sleptsova (2010) explained that economies of scale exhibited a variation of positive and negative effects on different sectors when it comes to exporting from Ukraine to EU. With firms coming from small domestic markets, the effect of economies of scale is very diminutive in determining the performance of these firms in foreign markets (Helpman, 1984 and Ethier, 1979).

Product diversification has been noticed by scholars in studying about international trade as its importance on the penetration of firms to foreign markets. Hopttop et al. (2005) examined whether exporters' performance was manipulated by product specialization or diversification. The result showed that firms being able to develop more diverse products had better export sales than those are not. Arrow (1962) postulated a theory of learning by doing whereby firms can learn by exporting an increasing number of new products. In other cases, launching a new product presents a firm's innovation capacity. In contrast, Balwin and $\mathrm{Gu}$ (2004) emphasized on product specialization which implied that when entering export market, firms tend to focus on a particular range of products rather than a variety of items which allows for exploitation of scale economies. Similarly, Amable (2000), Laursen (2000) and Peneder (2002) showed their empirical results which stressed the impact of product specialization on export trade. However, Funke and Ruhwedel (2001) found that product diversification is only significant in the industry of capitalintensive products, while in that of labor-intensive, more diverse products do not express any inconsistency in export performance.

For a long time, at firm-level internationalization, business governance has been taken as a main determinant for the successful establishment of export firms. In recent theories about international trade, the focal point has been migrated to another entity-firm's productivity or firm's efficiency. This notion literally broadened the scope of research of 
trade internationalization at micro-level. Melitz (2003) featured firm's productivity as the major determinant for export firms in entering foreign markets. Furthermore, evidences from numerous literatures in different countries such as Sofronis et al. (1998) for Colombia, Mexico, and Morocco; Bernard and Jensen (1999) for the United States; BeeYan Aw et al. (2000) for Taiwan exhibited the similitude in the sense that productive firms tend to be more adaptable to confront the adversity of foreign markets than other ones. Moreover, Sleptsova (2010) and Bernard and Jensen (2004) addressed that productivity is prerequisite when determining firms on entry foreign markets. Meanwhile, Wagner (2007) stressed that there is no such strong correlation between export activity and labor productivity or total factor productivity. Likewise, the question of whether exporting in turn raises productivity is also mentioned by Biesebroeck (2005), Loecker (2007), Mukim (2011), Delgado et al. (2002).

A firm operating for a long period of time may be more experienced than a newborn one because this firm can learn from doing. Older firms can generate cumulative skills, they are therefore expected to perform better than the younger (Majumdar, 1997; Iyer, 2010; Fakih and Ghazalian, 2013; Javalgi et al. 2000). Nevertheless, there are some controversial arguments. Older firms seem to be less flexible to adapt to new markets, resulting in lower export performance compared with the younger one (Amornkitvikai et al. 2012).

Type of firm ownership also plays an important effect on firm performance in which difference of organizational characteristics and managerial styles could lead to different performance outcomes. Many studies stated that state-owned firms perform worse than foreign firms (Aggrey et al. 2010; Rankin et al. 2005; Javalgi et al. 2000; Farole and Winkle, 2011; Özçelic and Taymaz, 2003). It could be explained that foreign owned firms gain the highest competiveness in not only low production cost which is resulted from their technology transfer to less developed regions but also wider destination markets, created by achieving better management skills.

Examining determinants for trade orientation of exporting firms is of crucial importance especially to firms from a developing country such as Vietnam. However, until now, there has 
not been any study which investigates export trade direction of Vietnamese footwear sector. This paper is the first to examine if the above mentioned determinants are relevant to identify firms' export direction as well as their export market selection. As such, our paper addresses the following research questions:

1. Is there any systematical difference between Vietnamese footwear firms exporting to the USA, EU and ASEAN markets?

2. Does export scale affect the destination markets of footwear firms such as the USA, EU and ASEAN markets? In other words, do the economies of scale stimulate footwear firms' exports to these markets?

3. Does the export diversification relate to the market orientation of Vietnam's footwear firms?

4. Are the FDI firms more dominant in internationalization and market penetration of footwear firms?

The remainder of this paper is organized as follows. Section 2 gives an overview of Vietnam's footwear exports for a 2006-2010 period. Section 3 explains the methodology and data. The regression results are reported in section 4 . The last section concludes the paper.

\section{Overview of Vietnam's footwear exports}

The charts below show the total number as well as the export values of Vietnam's footwear firms to top ten prominent markets from 2006 to 2010. Figure 1 clearly shows that countries with strong economic power such as the USA, UK and Germany are the most attractive destination markets to Vietnamese firms especially there are nearly 190 Vietnam's footwear firms exporting to the USA in 2006. Interestingly, the number of Vietnam's footwear firms exporting to these countries has been decreasing with time yet the export values have been being on the upward trend as seen in the Figure 2. There are less and less Vietnam's companies exporting to the USA but the value that they brought back has been growing overtime and registered as the one with largest export values of approximately USD 1.2 billion in 2010 . 
Figure 1: The total number of Vietnam's footwear firms to some destination markets (2006-2010)

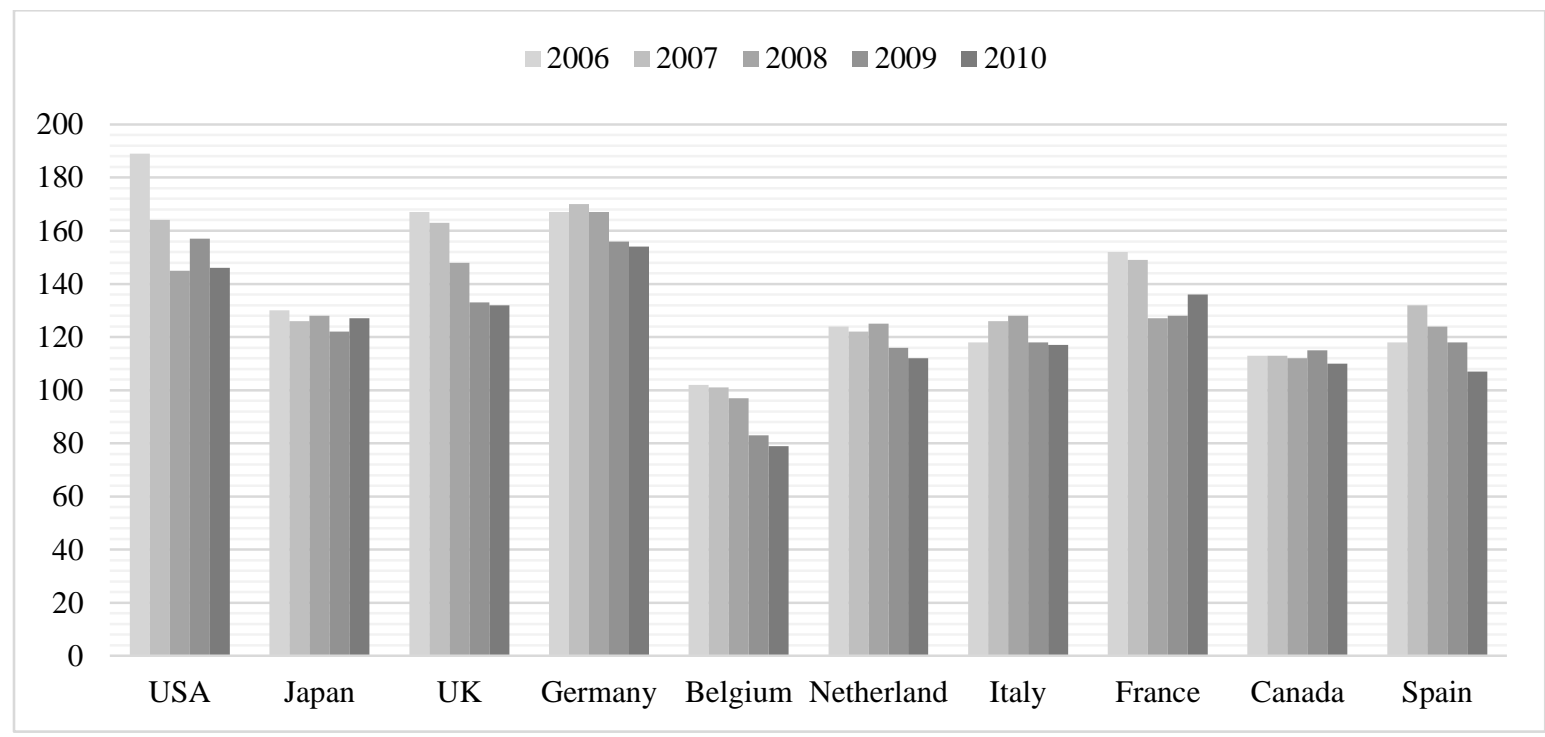

Figure 2: The export values of Vietnam's footwear firms to some destination markets from 2006-2010

(Bil. USD)

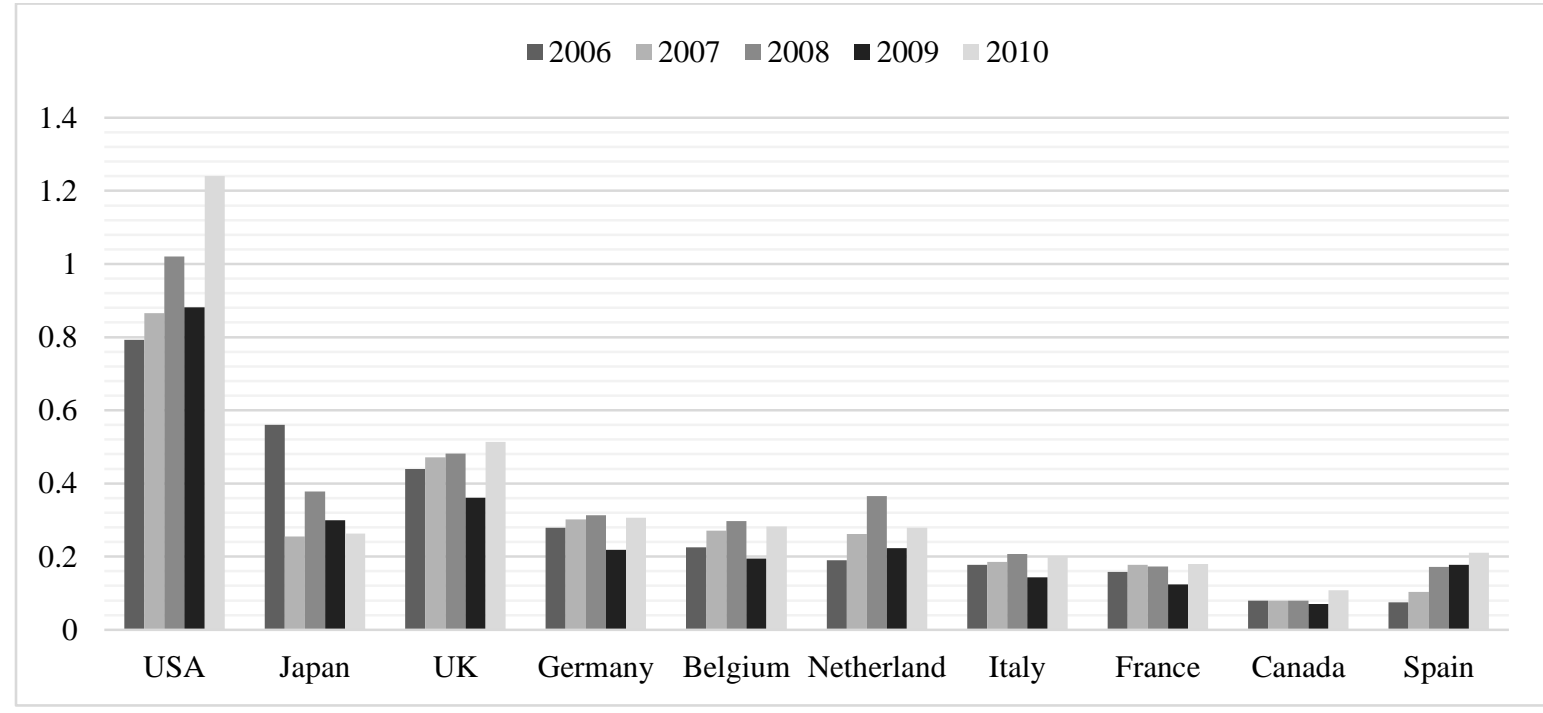

Source: General Department of Vietnam's Custom

Japan as the prominent market of Vietnam's footwear products has been noted with the reduction in value throughout years from over USD 0.55 billion in 2006 to less than USD 0.3 billion in 2010 . 
Notably, even though the numbers of firms among the USA, UK and Germany are comparable to each other, the export values to UK and Germany are only less than a half of that to the USA. This phenomenon proved the fact that most Vietnam's footwear exporting firms to the USA are able to conclude high valued contracts. Meanwhile, firms which export to other countries like France, Spain, Canada and Italy are almost small and medium size ones with most figures for export values.

Figure 3: Footwear export value 10 largest destination markets (2006-2010)

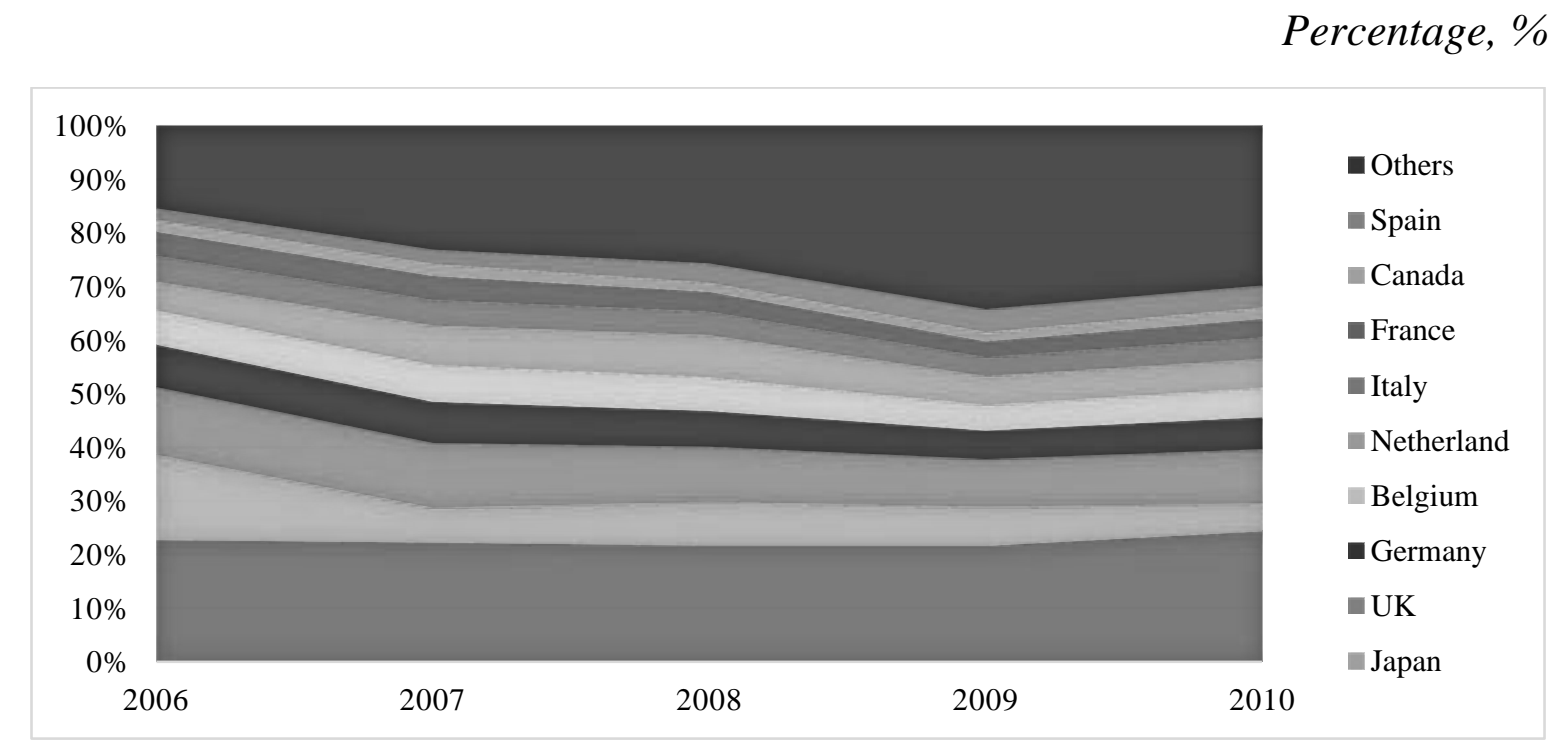

Source: General Department of Vietnam's Custom

The Figure 3 illustrates the proportions of the export values of Vietnam's footwear exports firms broken by destination markets. Overall, the percentages of export values to the USA, UK, Germany and Belgium have been steady throughout the years. It is clearly stated that the total exports to the USA account for large amount at over $20 \%$ over the period. As seen from previous descriptions, the export value to Japan has been declining throughout years which were manipulated in the reduction in the percentages over the total export value from $16 \%$ in 2006 to $5.2 \%$ in 2010.

For country groups, Vietnam's footwear products were exported to 24 countries in EU region including Austria, Belgium, Bulgaria, Cyprus, Germany, Denmark, Spain, Estonia, Finland, France, Greece, Hungary, Italy, Lithuania, Luxembourg, Latvia, Malta, 
Netherlands, Poland, Portugal, Slovakia, Slovenia, Sweden and Ukraine. Similarly, ASEAN group consists of Thailand, Brunei, Laos, Malaysia, Singapore, Philippines, Cambodia, Indonesia and Myanmar. EU as the whole accounted for the largest share in the total export values of Vietnamese footwear. The USA came in second place with around $23 \%$.

Table 2. Footwear export value to country and country groups (2006-2010)

(Mil. USD)

\begin{tabular}{|l|l|l|l|l|l|l|l|l|l|l|}
\hline \multirow{2}{*}{$\begin{array}{l}\text { Country } \\
\text { groups }\end{array}$} & \multicolumn{2}{|c|}{2006} & \multicolumn{2}{|c|}{2007} & \multicolumn{2}{c|}{2008} & \multicolumn{2}{|c|}{2009} & \multicolumn{2}{|c|}{2010} \\
\cline { 2 - 11 } & EV & $\begin{array}{l}\% \text { of } \\
\text { total }\end{array}$ & EV & $\begin{array}{l}\% \text { of } \\
\text { total }\end{array}$ & EV & $\begin{array}{l}\% \text { of } \\
\text { total }\end{array}$ & $\begin{array}{l}\text { EV } \\
\text { total }\end{array}$ & $\begin{array}{l}\text { EV of } \\
\text { total }\end{array}$ \\
\hline USA & 793 & 22.7 & 866 & 22.2 & 1028 & 21.7 & 881 & 21.6 & 1244 & 24.3 \\
\hline EU & 1241 & 35.5 & 1487 & 38.1 & 1718 & 36.6 & 1220 & 30 & 1624 & 40 \\
\hline ASEAN & 61.9 & 1.8 & 125 & 3.2 & 57.4 & 1.2 & 103 & 2.5 & 70.7 & 1.4 \\
\hline NUEA & 1560 & 40 & 1410 & 36.5 & 1930 & 40.5 & 1933 & 45.9 & 2203 & 34.3 \\
\hline
\end{tabular}

Source: General Department of Vietnam's Custom

Surprisingly, ASEAN is not an attractive market for Vietnam's footwear export when there is only around $2 \%$ of the total export values are benefited from this region. All in all, while the USA and EU markets dominated the proportion of total export values with more than $60 \%$ in 2010 , the rest is from other markets in the world.

In terms of type of firm's ownership, it is obviously shown that FDI companies ${ }^{4}$ generated the largest revenue in the market of Vietnam's footwear exports. These firms' export values accounted for approximately $65 \%$ of the total and on the increasing trend. About private firms ${ }^{5}$, the export value increased throughout years but in comparison to the whole, the proportion has sunk from $33.2 \%$ in 2006 to $28.6 \%$ in 2010. Finally, SOEs export value

\footnotetext{
${ }^{4}$ A firm operates in the form of either establishing business operations or acquiring business asset in another country.

${ }^{5}$ A firm is operated by private and local individuals.
} 
deposited very modestly and after the peak in 2008 , it is on the vast declining trend and notably, SOEs did not contribute as much as the private and FDI enterprises did.

Table 3. Export value by type of firm ownership (2006-2010)

Mil. USD

\begin{tabular}{|l|l|l|l|l|l|l|l|l|l|l|}
\hline \multirow{2}{*}{$\begin{array}{l}\text { Types of } \\
\text { firm's } \\
\text { ownership }\end{array}$} & \multicolumn{2}{|c|}{2006} & \multicolumn{2}{c|}{2007} & \multicolumn{2}{c|}{2008} & \multicolumn{2}{c|}{2009} & \multicolumn{2}{c|}{2010} \\
\cline { 2 - 11 } & EV & $\begin{array}{l}\% \text { of } \\
\text { total }\end{array}$ & EV & $\begin{array}{l}\% \text { of } \\
\text { total }\end{array}$ & EV & $\begin{array}{l}\% \text { of } \\
\text { total }\end{array}$ & $\begin{array}{l}\text { EV } \\
\text { total }\end{array}$ & $\begin{array}{l}\text { EV of } \\
\text { total }\end{array}$ \\
\hline SOEs & 123 & 3.3 & 143.1 & 3.6 & 291 & 5.3 & 123 & 3 & 66.3 & 1.2 \\
\hline Private & 1230 & 33.2 & 1125 & 28.8 & 1730 & 30 & 1329 & 32.4 & 1460 & 28.6 \\
\hline FDI & 2303 & 63.5 & 2621 & 67.6 & 3346 & 64.7 & 2586 & 64.6 & 3616 & 70.2 \\
\hline
\end{tabular}

Source: General Department of Vietnam's Custom

Table 3 and Table 4 indicate the export value and the number of firms by types of firm ownership in which the number of SOEs in footwear sector has decreased throughout years between 2006 and 2008.

Table 4. Number of firms by types of ownership

\begin{tabular}{|l|c|c|c|c|c|c|c|c|c|c|}
\hline \multirow{2}{*}{$\begin{array}{l}\text { Types of } \\
\text { firm's } \\
\text { ownership }\end{array}$} & \multicolumn{2}{|c|}{2006} & \multicolumn{2}{|c|}{2007} & \multicolumn{2}{|c|}{2008} & \multicolumn{2}{|c|}{2009} & \multicolumn{2}{|c|}{2010} \\
\cline { 2 - 11 } & $\begin{array}{l}\text { No of } \\
\text { firms }\end{array}$ & $\begin{array}{l}\% \text { of } \\
\text { total }\end{array}$ & $\begin{array}{l}\text { No of } \\
\text { firms }\end{array}$ & $\begin{array}{l}\% \text { of } \\
\text { total }\end{array}$ & $\begin{array}{l}\text { No } \\
\text { of } \\
\text { firms }\end{array}$ & $\begin{array}{l}\% \text { of } \\
\text { total }\end{array}$ & $\begin{array}{l}\text { No } \\
\text { of } \\
\text { firms }\end{array}$ & $\begin{array}{l}\text { of of } \\
\text { total }\end{array}$ & $\begin{array}{l}\% \text { of } \\
\text { firms } \\
\text { total }\end{array}$ \\
\hline SOEs & 44 & 9.4 & 33 & 7.7 & 26 & 6.9 & 25 & 6.5 & 15 & 4.1 \\
\hline Private & 252 & 54.1 & 239 & 56.1 & 189 & 50.8 & 197 & 51.4 & 249 & 69.3 \\
\hline FDI & 170 & 36.5 & 154 & 36.2 & 157 & 42.3 & 161 & 42.1 & 95 & 26.6 \\
\hline
\end{tabular}

Source: General Department of Vietnam's Custom

As seen in Table 4, private firms dominate the sector, accounting around $55 \%$ of the total. The upward trend also explains their share in export value. On the other hand, the number of FDI firms was smaller than that of private firms however accounting the largest share in 
export value. The notion stressed out the importance of FDI firms in the export activities of Vietnam's footwear.

The ages of Vietnamese footwear firms ranged from 1 to 53 years. From the Figure 4, nearly $60 \%$ of export firms are young companies the years of establishment of which are less than ten years and firms aging from 11 to 20 years account for $37 \%$ of the total.

Figure 4: The ages of footwear firms (percentages)

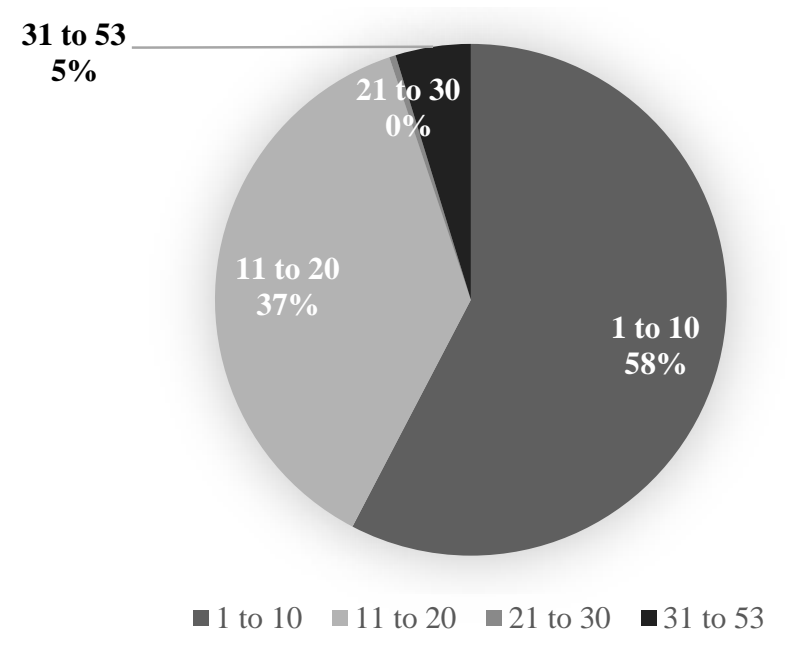

Source: Authors' calculation based on Stata 14.

Notably, vast majority of firms falling in these categories are private and FDI enterprises.

Older firms aging more than 20 years accounted for only $5 \%$ and are mostly SOEs.

Table 5. Export values by types of ownerships to destination markets (2006-2010)

\begin{tabular}{|l|c|c|c|c|}
\hline $\begin{array}{c}\text { Types of firm's } \\
\text { ownership }\end{array}$ & USA & EU & ASEAN & NUEA \\
\hline SOEs & 2.46 & 72.52 & 12.32 & 61.72 \\
\hline Private & 108.24 & 459.44 & 24.66 & 655.94 \\
\hline FDI & 745.36 & 926.08 & 102.92 & 1089.7 \\
\hline
\end{tabular}

Source: General Department of Vietnam Customs

From the Table 5, it is clearly seen that FDI firms continue to dominate regarding their export values by destination market. Both private and FDI firms did not focus on ASEAN market but export to very important markets such as EU and the USA. In contrast, SOEs 
did not concentrate on the USA market obtaining the export value of only USD 2.46 billion over the period while the EU and ASEAN became their major importing country groups respectively.

\section{Data and methodology}

\subsection{The model}

We apply the multinomial logit model to measure and analyze the determinants affecting the choices of market entry of Vietnamese footwear firms including the USA, EU and ASEAN markets. This model allows us to identify the percentage of firms exporting to any markets in a particular year and the maximum value of exports gained by a firm as follows:

$$
P_{\text {in }}=\frac{\exp \left(V_{\text {in }}\right)}{\exp \left(V_{\text {im }}\right)+\exp \left(V_{\text {in }}\right)+\exp \left(V_{i q}\right)+\exp \left(V_{i p}\right)}
$$

Where $V_{i n}$ is the utility function of the destination country $n$ for firm $i$

$V_{i m}$ is the utility function of destination country $m$ for firm $i$

$V_{i q}$ is the utility function of destination country $q$ for firm $i$

$V_{i p}$ is the utility function of destination country $p$ for firm $i$

$V_{i n}=\alpha+\beta_{1} X_{1}+\beta_{2} X_{2}+\ldots .+\beta_{k} X_{k}$

And $P_{i n}$ is the probability of market entry ${ }^{n}$ of firm ${ }^{i}$

The multinomial logit which is applied in this study includes:

* Dependent variable: includes 4 nominal variables such as the USA, EU, ASEAN and NEAU (country group does not cover EU, US and ASEAN countries).

* Independent variables:

- Total value of export of firm $i$ in year $t$ measures firm's specialization.

- Number of footwear products of firm $i$ in year $t$ measures the product diversification of a firm.

- Labor productivity of firm $i$ in year $t$ is identified by dividing a firm's revenue by its total number employees.

- Age of firm is identified upon the year of establishment. 
- Dummy variable SOE takes the value 1 if a firm is owned by the State or zero otherwise; Private variable takes the value 1 if a firm is owned by a single individual or zero otherwise; FDI takes the value 1 if its state is owned by a person or company from a foreign country or zero otherwise.

\subsection{Data}

This paper uses micro data of Vietnam's footwear firms for a period from 2006 to 2010. The dataset includes firm identity code, the name and code of importing country, transaction code, currency code, exchange rate, export volume, unit price, and export value in the foreign currency $^{6}$, name of product and its code at 10 -digit SITC level. The data was supplied by General Department of Vietnam's Customs (GDVC). This government-based body is responsible for managing export and import activities of firms in Vietnam as well as collecting data on their exports and imports. Firms who have the need to export or import goods are required to complete a declaration sheet to a border gate customs sub-department of the GDVC. In details, the first data set contains about 127 footwear firms involving in export activities. In fact, there are 15 types of currency are used for trade transaction, we converted firms' transaction value into Vietnamese Dong by using the exchange rate notified by Vietnam's State bank at the date of transaction.

\section{Empirical results}

The empirical results reported in Table 6 present the estimates using the pooled OLS approach for multinomial logistics regression model with data over the 2006-2010 period. The value of exports in VND adjusted by GDP deflator is shown in the form of natural logarithms and all coefficients are corrected for standard errors.

Export value indicating the scale effects gives a positive and significant effect on trade flows from Vietnam to the USA and European countries during the period of 2006 - 2010 while it is negative and significant at $1 \%$ for footwear firms exporting to ASEAN

\footnotetext{
${ }^{6}$ Payment currency in export contract includes AUD, CAD, CHF, CNY, EUR, GBP, HKD, JPY, MYR, NOK, SGD, TWD, USD, USR, and VND.
} 
countries. In other words, footwear firms are more likely to be attracted by the USA and European markets rather than ASEAN. The USA and EU are known to capture major market segment of the international market and it seems that Vietnam has achieved a degree of specification in footwear sector in trade with the US and the EU.

Table 6. Dependent variables: USA, EU, ASEAN, 2006 - 2010

\begin{tabular}{|c|c|c|c|}
\hline Independent variables & USA & EU & ASEAN \\
\hline Exportvalue $_{i j t}$ & $\begin{array}{c}0.155^{* * * *} \\
(4.48)\end{array}$ & $\begin{array}{c}0.158 * * * \\
(2.7)\end{array}$ & $\begin{array}{c}-0.117 * * * \\
(-3.35)\end{array}$ \\
\hline Numproduct $_{i j t}$ & $\begin{array}{c}0.0467 \\
(1.41)\end{array}$ & $\begin{array}{c}-0.0716 \\
(-1.46)\end{array}$ & $\begin{array}{c}0.0975 * * \\
\quad(2.30)\end{array}$ \\
\hline Productivity $_{i t}$ & $\begin{array}{c}0.227 * * * \\
(8.88)\end{array}$ & $\begin{array}{c}-0.0540 \\
(-1.26)\end{array}$ & $\begin{array}{c}0.187 * * * \\
(3.58)\end{array}$ \\
\hline Firmage $_{i t}$ & $\begin{array}{c}-0.318 * * * \\
(-9.50)\end{array}$ & $\begin{array}{c}-0.0516 \\
(-0.93)\end{array}$ & $\begin{array}{c}-0.115 * * \\
(-2.50)\end{array}$ \\
\hline Privates & $\begin{array}{c}0.281 * * * \\
(5.13)\end{array}$ & $\begin{array}{c}-0.271 * * * \\
(-4.03)\end{array}$ & $\begin{array}{c}0.0613 \\
(0.41)\end{array}$ \\
\hline FDIs & $\begin{array}{c}-0.341 * * * \\
(-2.50)\end{array}$ & $\begin{array}{c}-0.774 * * * \\
(-4.95)\end{array}$ & $\begin{array}{l}0.293 \\
(1.16)\end{array}$ \\
\hline Constant & $\begin{array}{c}-9.297 * * * \\
(-7.31)\end{array}$ & $\begin{array}{c}-2.013 * * * \\
(-1.34)\end{array}$ & $\begin{array}{c}-3.205 * * * \\
(-2.65)\end{array}$ \\
\hline Observations & & 21370 & \\
\hline Year dummies & & $318.55 * * *$ & \\
\hline Wald chi2(30) & & 2052.66 & \\
\hline $\mathrm{P}>$ chi 2 & & 0.000 & \\
\hline Pseudo $\mathrm{R}^{2}$ & & 0.027 & \\
\hline
\end{tabular}

Source: Author's calculation using STATA 14.

Number of product showing Vietnam' footwear firms' commodity diversification affects negatively the possibility of firms to export to the EU showing that firms with higher specialization tend to export to EU meanwhile it is positive but insignificant for firms serving the US market. The product diversification factor show positive and significant sign if firms exports to the ASEAN market. To put it differently, firms with heterogeneous 
products tend to choose the ASEAN market to export. Funke and Ruhwedel (2001) found that export diversification is expected to have positive connection with economic growth in transition time. Similarly, Vietnam is experiencing product diversity when exporting to demanding markets. It should also be noted that there is not enough evident to conclude that Vietnamese footwear firms are more likely to export to the USA although this indicator shows positive sign in the US market.

In line with a variety of papers implying that more productive firms could reach more distant and large markets (Bastos and Silva, 2010; Bernard and Jensen, 2004; Bernard and Wagner, 1997; Bigsten et al. 2000; Clerides et al. 1998; Fernandes and Isgut, 2005; Wagner, 2007; Muûls and Pisu, 2009), our findings indicate that firms' labor productivity shows the positive and significant effect to their direction of export trade to the USA and ASEAN. However, it captures a negative and insignificant sign when firms decide to choose EU as their destination market.

A negative sign of firm age is found in all markets including both the distant markets such as the US and the surrounding market such as the ASEAN. That means young firms dominate the footwear export sector of Vietnam. While it found to be significant for the case of firms exporting to the US and ASEAN at $1 \%$ and 5\% respectively, it is insignificant when firms export to the EU. In fact, many studies on determinants of exports show no effect of firm age with respect to export performance (Sousa and Bradley, 2009; Papadogonas et al 2007; Rankin et al. 2006; Robson et al. 2012; Iyer, 2010). There are some possible explanations for the mixed effect of firm age. On the one side, a longestablished firm is more likely to accumulate managerial skills, financial capacity and understanding of the law of foreign markets. In contrast, young firms may not have enough experience to compete with their larger international rivals when launching a global competition campaign. On the other side, although older firms should be more efficient through their learning-by-doing process (Amornkitvikai et al. 2012), younger firms tend to be more dynamic, thus finding it easier to adapt to changes in the law and business environment overseas. 
Ownership of firms may generate obstacle for firms in decision to choose their destination markets. Both private and FDI firms are less likely to export to the EU compared with their counter parts owned by the State (SOEs). In fact, SOEs in Vietnam get official priority that benefit from financial grants from the government budget with lower corporation tax rate and easy access to state funds and real estate. It also shows positive but insignificant sign of trade flow from Vietnam to the ASEAN in private and FDI sectors. Interestingly, for firms choosing the US as their destination markets, private firms are shown to be more dynamic than the FDI firms. However, foreign firms have been found to be more effective in enhancing their export performance (Aggrey et al. 2010; Özçelic and Taymaz, 2003; Farole and Winkler, 2011; Michiel, 2002).

\section{Firm's types of ownership: Does it matter?}

Because the role of the FDI footwear firms is important in terms of export trade value in almost all markets, we tried to test whether our regression results remain robust if firms owned by different entities are sequently dropped out of the dataset. Table 7 shows that the results mostly remain to be consistent with those mentioned in the previous section when FDI and SOE firms are sequently excluded from the dataset.

When excluding both Privates and FDI firms from the sample, the significant level of export value indicator reduces statistically from $1 \%$ at all markets to $1 \%, 5 \%$ and $10 \%$ in the USA, EU and ASEAN respectively. It also shows in table 7 and table 8 that SOE firms have stronger possibility to export to the US as the coefficient of this indicator changes from 0.155 to 0.376 . Remarkably, while the product diversification indicator shows a positive effect for firms exporting to the ASEAN market, it is significantly negative if SOE firms seek for EU as their destination market. The finding is in line with the literature that SOE firms seem to be less effective than the others in terms of attempting to diversify export product items. For firms serving the US market, as the sign of product diversification changes from positive to negative with the coefficient from 0.0467 to 0.0508 and is consistently insignificant. In addition, robustness test result presents that firm age is no longer a significantly important factor that hampers the probability of SOE firms 
to export to the ASEAN. In other words, we do not have enough evidence to state that the younger firms are less likely to export to the ASEAN and vice versa. However, one important point to note in the table 8 is that, low productive firms serving the EU market are owned by the State.

Table 7. Regression results with different types of firms' ownership

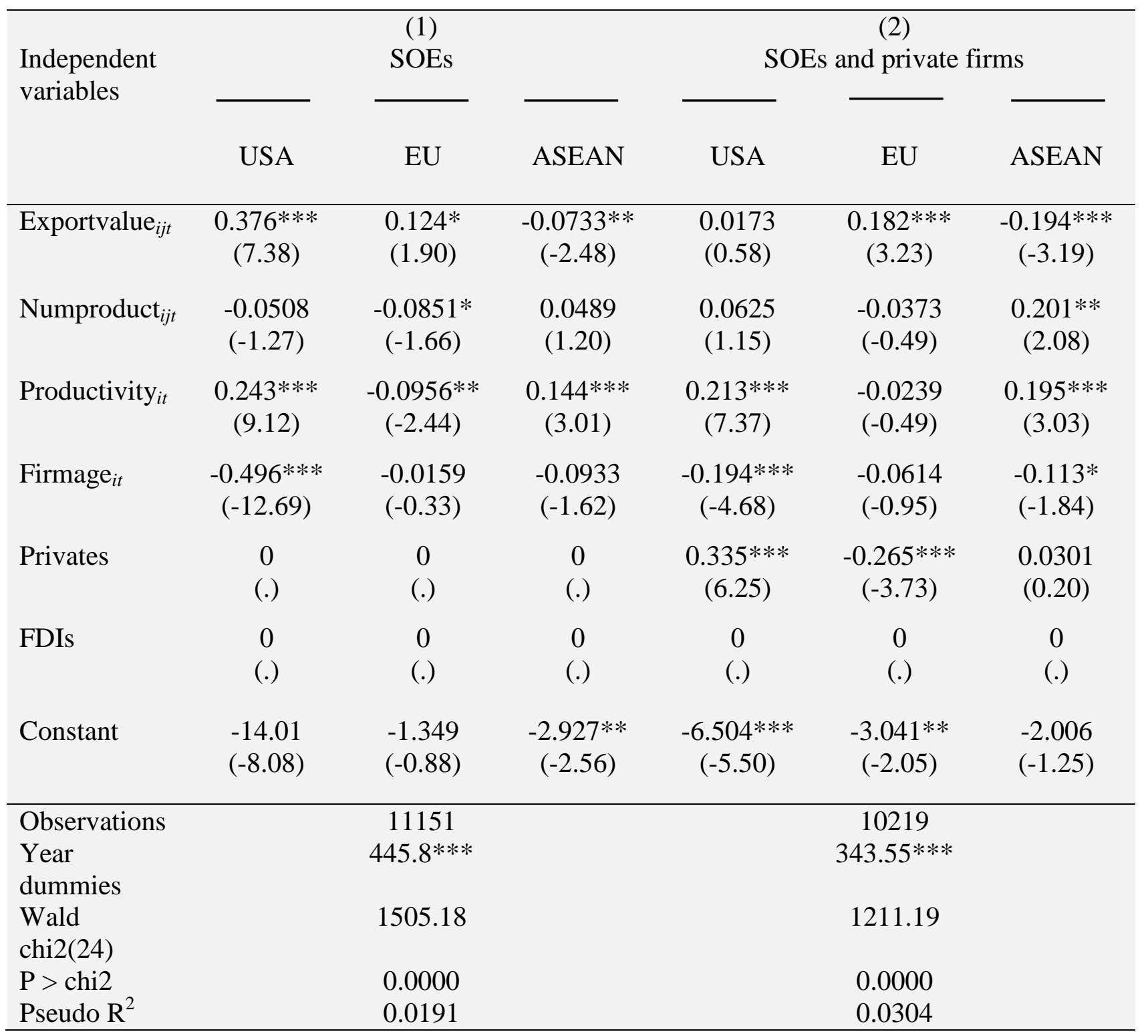

Source: Author's calculation using STATA 14.

When only SOEs and private enterprises are included in the dataset, we do not find any change of sign in all indicators. Nevertheless, we found the differences in significant level 
in the robustness result. Specifically, export value is not significant factor that affects export trade flow from Vietnam to the USA while it performs a crucial part in the EU and ASEAN markets. In addition, the product diversification indicator also loses its role in the EU market when the insignificant rate changes are found, meaning that it is statistically uncertain that heterogeneous firms tend not to export to the EU. More importantly, both SOE and private firms become influential determinants in the USA at $1 \%$ significant emphasizing that these both types of business ownership in the model have high probability to export to the USA. 


\section{Conclusion}

The paper analyzes various determinants of Vietnam's footwear firms' market selection. We are particularly interested in examining the effects of firms' scale as well as their product diversification. To some extent, firms' export scale present how they can specialize in serving the international market and firms' product diversification shows their product innovation. Our finding shows that there is a systematical difference between Vietnamese footwear firms exporting to the US, EU and ASEAN markets.

The regression results of the pooled cross sectional multinomial logit model show that footwear firms are more likely to target to the US and EU markets. Although these markets are, in fact hardly to penetrate, they become more attractive rather than the remaining ones including the ASEAN countries. Surprisingly, firms exporting to the EU market are less likely to diversify products whereas the demand for different types of products is seen to be higher in the ASEAN countries. 


\section{Reference}

Aggrey N., Eliab. L., Joseph S. 2010. Determinants of Exports Participation in East African Manufacturing Firms, Current Research Journal of Economic Theory, 2(2), $\quad$ 55-61.

Amable B. 2000. International Specialisation and Growth Structural Change and Economic Dynamics, 11(4), 413-432.

Amornkitvikai Y., Harvie C., T. Charroenrat. 2012. Factors Affecting the Export Participation and Performance of Thai Manufacturing Small and Medium Sized Enterprises (SMEs), 57th International Council for Small Business World Conference, 1-36, Wellington, New-Zealand.

Arrow K.J. 1962. Economic Welfare and the Allocation of Resources for Invention. Welfare Economics and Inventive Activity, 609-626.

Aw B., Chung Y.S., Roberts M.J. 2000. Productivity and Turnover in the Export Market: Micro-Level Evidence from the Republic of Korea and Taiwan (China). World Bank Economic Review, Oxford University Press, 14 (1), 65-90.

Balwin R.J., Gu W. 2004. Innovation, Survival and Performance of Canadian Manufacturing Plants, Statistics Canada Catalogue no. 11F0027M. Economic Analysis (EA) Research Paper Series. No. 22.

Bastos P., Silva J. 2010. The Quality of a Firm's Exports: Where You Export to Matters, Journal of International Economics, 82, 99-111.

Bernard A.B., Jensen J.B. 1999. Exceptional Exporter Performance: Cause, Fffect or Both?, Journal of International Economics, 47(1), 1-25.

Bernard A.B., Wagner J.B. 1997. Exports and Success in German Manufacturing, Weltwirtschaftliches Archiv/Review of World Economics, 137(1), 105-23.

Bernard A.B., Jensen J.B. 2004. Exporting and the Productivity in the USA, Oxford Review of Economic Policy, 20(3), 343-57.

Biesebroeck J.V. 2005. Exporting Raises Productivity in Sub-Saharan African Manufacturing Firms, Journal of International Economics, 67, 373-91.

Bigsten A., Collier P., Dercon S., Fafchamps M, Gauthier B, Gunning J.W., Oduro A., Oostendorp R., Pattillo C., Söderbom M., Teal F., Zeufack A. 2000. Exports and Firm-Level Efficiency in African Manufacturing Mimeo. Centre for the Study of African Economies at Oxford University, Oxford.

Clerides S., Lach S., Tybout J. 1998. Is Learning by Exporting Important? MicroDynamic Evidence From Colombia, Mexico and Morocco, Quarterly Journal of Economics 113, 903-48.

Delgado W.A., Fariñas J.C., Ruano S. 2002. Firm Productivity and Export Markets: A NonParametric Approach, Journal of International Economics, 57, 397-422. 
Ethier W.J. 1979. Internationally decreasing costs and world trade, Journal of International Economics, 9, 1-24.

Fakih A., Ghazalian L.P. 2013. Why Some Firms Export? An Empirical Analysis for Manufacturing Firms in the MENA Region. IZA DP No. 7172.

Farole T., Winkler D. 2011. Firm Location and the Determinants of Exporting in Developing Countries, International Trade Department of the World Bank, Policy Research Working Paper 5780.

Fernandes A.M., Isgut A.E. 2005. Learning-by-Doing, Learning-by-Exporting, and Productivity: Evidence from Colombia, Policy Research Working Paper Series 3544, the World Bank.

Funke M., and Ruhwedel R. 2001. Product variety and economic growth: Empirical Evidence for the OECD countries, IMF Staff Papers No. 48, 225-42.

Helpman E. 1984. A Simple Theory of International Trade with Multinational Corporations, Journal of Political Economy, 92(3), 451-71.

Hottop U., Radosevic S., Bishop K. 2005. Trade and Industrial Upgrading in Countries in Central and Eastern Europe: Patterns of Scale and Scope-Based Learning. Emerging Markets, Finance and Trade, 41(4), 20-37.

Iyer K. 2010. The Determinants of Firm-Level Export Intensity in New Zealand Agricultural and Forestry, Economic Analysis \& Policy, 40(1), 75-86.

Javalgi G.R., White D.D., Lee. O. 2000. Firm Characteristics Influencing Export Propensity: an Empirical Investigation by Industry Type. Journal of Business Research, 47(3), 217-28.

Krugman P.R. 1980. Scale Economies, Product Differentiation, and the Pattern of Trade, The American Economic Review, 70(5), 950-59.

Laursen K. 2000. Trade Specialisation, Technology and Economic Growth - Theory and Evidence from Advanced Countries. Cheltenham, UK.

Loecker J. 2007. Do Exports Generate Higher Productivity? Evidence from Slovenia, Journal of International Economics, 37, 69-98.

Majumdar K.S. 1997. The Impact of Size and Age on Firm-Level Performance: Some Evidence from India, Review of Industrial Organization, 12, 231-41.

Melitz M.J. 2003. The Impact of Trade on Intra-Industry Reallocations and Aggregate Industry Productivity, Econometrica, 71(6), 1695-1725.

Michiel V.D. 2002. The Determinants of Export Performance in Developing Countries: The Case of Indonesian Manufacturing, Eindhoven Centre for Innovation Studies, Working Paper 02.01, Department of Technology Management, Technische Universiteit Eindhoven, The Netherlands.

Mukim M. 2011. Does Exporting Increase Productivity? Evidence from India, World Bank Paper Series. 
Muûls M and Pisu M. 2009. Imports and Exports at the Level of the Firm: Evidence from Belgium, The World Economy, 32(5), 692-734.

Özçelic E., Taymaz. E. 2003. Does Innovativeness Matter for International Competitiveness in Developing Countries? The Case of Turkish Manufacturing Industries, Research Policy, 33, 409-24.

Papadogonas T., Voulgaris F., Agiomirgianakis G. 2007. Determinants of Export Behavior in the Greek Manufacturing Sector, Operational Research, 7(1), 121-35.

Peneder M. 2002. Industrial Structure and Aggregate Growth, WIFO Working Paper 182.

Rankin N., Söderbom M., Teal F. 2006. Exporting from Manufacturing Firms in SubSaharan Africa, Journal of African Economies, 15(4), 671-87.

Rankin N., Söderbom M.,Teal F. 2006. Exporting from Manufacturing Firms in Sub-Saharan Africa, Journal of African Economies, 15(4), 671-87.

Robson J.A., Akuetteh C.K., Westhead P., Wright M. 2012. Exporting Intensity, Human Capital and Business Ownership Experience, International Small Business Journal, 30(4), 36787.

Sleptsova E. 2010. Exports from Ukraine to the European Union: Macro -, Mirco- and Political Economy Determinants, Doctoral thesis, University of Birmingham.

Sofronis K.C., Saul L., James R.T. 1998. Is Learning by Exporting Important? Micro-Dynamic Evidence from Colombia, Mexixo, and Morocco. The Quarterly Journal of Economics, Oxford University Press, 113(3), 903-947.

Sousa C and Bradley. F. 2009. Effects of Export Assistance and Distributor Support on the Performance of SMEs: The Case of Portuguese Export Ventures, International Small Business Journal, 27(6), 681-701.

Wagner J. 2007. Exports and Productivity: A Survey of the Evidence from Firm-Level Data, The World Economy, 30(1), 60-82.

Wagner J. 2007. Exports and Productivity: A Survey of the Evidence from Firm-Level Data, The World Economy, 30(1), 60-82. 